\title{
QUATERNARY SOIL-GEOLOGICAL STRATIGRAPHY IN GREECE
}

Paepe R. ${ }^{1}$, Mariolakos I. ${ }^{2}$, Van Overloop E. ${ }^{1}$, Nassopoulou S. ${ }^{3}$, Hus J. ${ }^{4}$, Hatziotou M. ${ }^{5}$, Markopoulos T. ${ }^{6}$, Manutsoglu E. ${ }^{6}$, Livaditis G. ${ }^{7}$, Sabot V. ${ }^{7}$

${ }^{1}$ Environmental Research and Geological Consultants GEOBOUND INTERNATIONAL, Herzele, Belgium geobound@tiscalinet.be and Free University of Brussels, Belgium

${ }^{2}$ Department Geodynamic Geology, National and Kapodistrian University of Athens, Athens, Greecemariolakos@geol.uoa.gr

${ }^{3}$ Ministry of Environment, Athens, Greece snassopoulou@orsa.minenv.gr

${ }^{4}$ Centre de physique du globe, Institut royal de météorologie, Dourbes, Belgique

${ }^{5}$ Greek Archaeological Survey, Athens, Greece

${ }^{6}$ Mineralogical Resources and Engineering Department, Technical University of Crete, Chania, Crete, Greece markopou@mred.tuc.gr, emanout@mred.tuc.gr

${ }^{7}$ Department of Geography, Athens, National and Kapodistrian University of Athens, Greece

\section{ABSTRACT}

Peloponnesus and Crete are probably offering the best possible standard sections for Eastern Mediterranean Pleistocene Series. Complete Pleistocene Standard Lithostratigraphic Sections from Sparta (Peloponnesus) and Kandanos (Crete) reveal continuous Pleistocene Land Sequences composed of cyclic palaeosol levels interfering with clastic fluvial, eolian (loess) and gravel deposits comparable with analogues found elswhere over the earth. Most suitable for correlation are: a) the standard loess area of Northern Europe, Russia and China, and b) the subtropical and tropical regions of Africa and Asia. The standard Greek Pleistocene Lithostratigraphic Sequence independently recorded at both sites (and partially from sites in other regions of Greece) reveal a number of 103 palaeosols of both interglacial and interstadial stages, indicating the extreme warm to relative warm phases of the Plesstocene ice age. This number suits surprisingly well to the 103 levels of the equally warm odd numbered oxygen isotopic stages (OIS) of the Pleistocene deep sea record which equally encompass the warm phases of the Pleistocene.

Special attention is given to the Upper Pleistocene of Koroni (Southern Peloponnesus) as a case study for the Last Interglacial - Last Glacial Cycle, i.e. the middle term cycle extending in time from $127 \mathrm{Ka}$ (thousand years) till $10 \mathrm{Ka}$ or beginning of the Holocene. It stands as a model for the recurrent $100 \mathrm{Ka}$ cycles of the long term overall Pleistocene record. Finally, in addition to the Pleistocene, the twenty wet - dry cycles of the Holocene are reviewed.

\section{THE SOIL STRATIGRAPHIC PLEISTOCENE RECORD IN GREECE}

The Quaternary in this contribution is essentially dealing with the long-term record of Pleistocene of $2.4 \mathrm{Ma}$ (million years). The quaternary geological stratigraphy in Greece displays a time series of 103 (interglacial and interstadial) fossil soil (palaeosol) levels from which the climate-environmental conditions with respect to their development can be enhanced. Hence, soil-geological stratigraphy is an important tool in the understanding of the climatic evolution of the Quaternary.

\subsection{Why a soil-stratigraphic based Quaternary geology?}

1. After the 'Mediterranean Salinity Crisis' in Late Messinian times, due to tectonic events that cut off the Mediterranean Sea from the Atlantic Ocean, the region became isolated and climatically more continental. 
2. The Quaternary Greek land record based on soil series, as will be described in detail hereafter, thus became essentially a non marine system providing fluvial and desertic sediment series alternating with (fossil) soils. They are called 'Geosoil' to stress their geological affinity (Paepe et al. 1990).

Soils and Climate Change

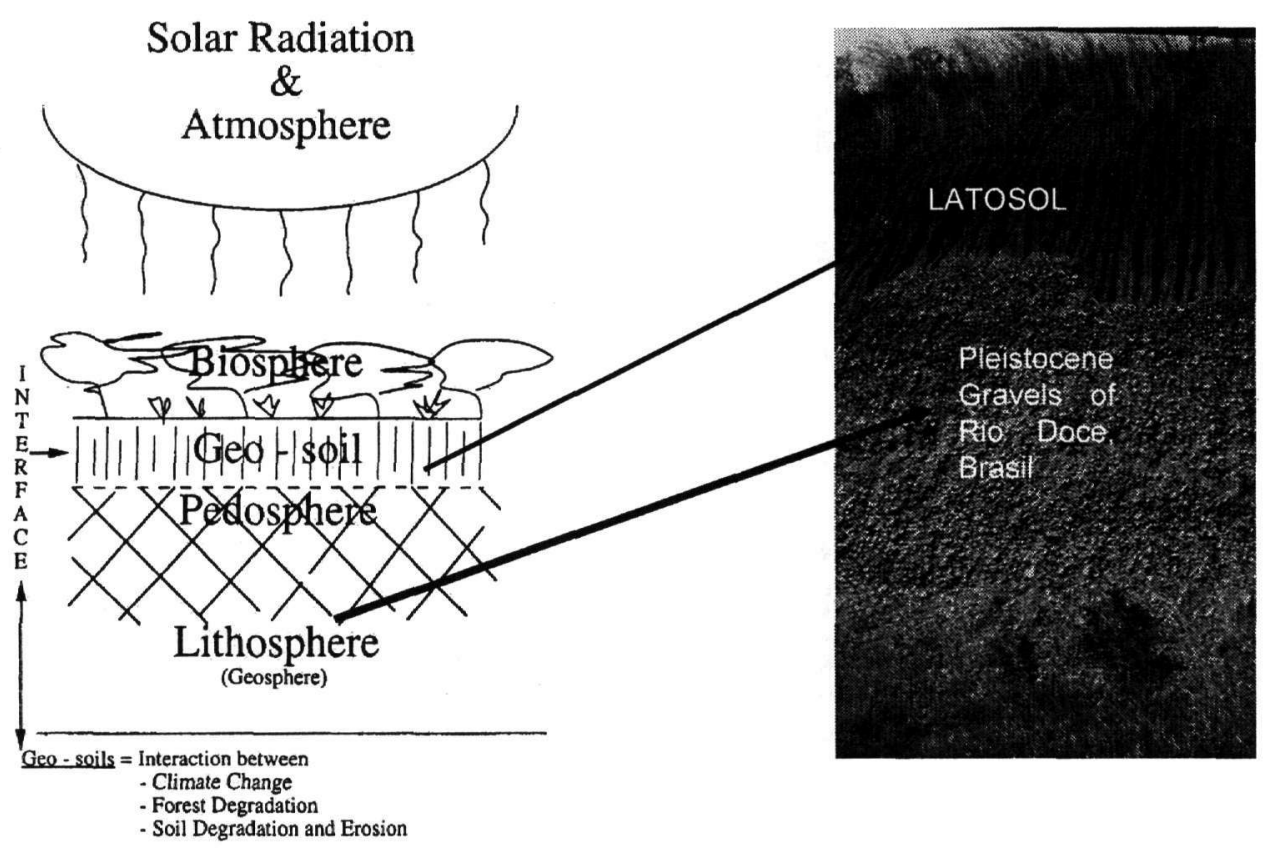

Figure 1. GEOSOIL: The interface between Biosphere and Lithosphere. Top of lithosphere reworked into Pedosphere (soil-sphere). Truncated pedosphere becomes geosoil. Atmospheric climatic changes via biosphere in pedosphere. GEOSOIL registers changes in atmosphere through time such as carbon dioxide changes.

3. Geosoils in Quaternary time series of lithostratigraphic sequences reveal to occupy 'time stable' stratigraphic positions and thus also suitable for time correlation just as the marine series.

4. Because Quaternary geosoil records also show worldwide a stable stratigraphic distribution, they are suitable for long distance correlation.

5. Geosoil-sediment series can therefore also offer good evidence of worldwide climatic changes on land through out the Quaternary Period.

6. Geosoils reflect changes in the local bio-environment as well as changes in the atmospheric chemistry (carbon dioxide).

7. The Greek soil-stratigraphic standard sequence (as described hereafter) reveals a total of 103 such fossil geo-soils, both interglacial and glacial-interstadial. They all occur above the basal Miocene Red Latosol and can be correlated with the 103 oxygen isotopic deep-sea record occurring above the geomagnetic Gauss/Matuyama boundary of $2.6 \mathrm{Ma}$ (Shackleton et al. 1990).

\subsection{Two important lithostratigraphic type-localities as a proposal for a Greek Land Quaternary Lithostratigraphic Record}

Amongst numerous lithostratigraphic sections observed all over Greece during the last twenty years, two retained utmost attention for the sake of completeness in their uninterrupted stratigraphic build up: the Sparta/Afission section in the Peloponnesus and Kandanos in the highlands of Crete. 


\subsubsection{Section Sparta/Afission}

The Sparta/Afission section revealed a complete Pleistocene continental sequence of fossil soils interfering with clastic fluvial and eolian deposits incorporated between a series of Holocene top layers and a series of Plio/Miocene basic layers.

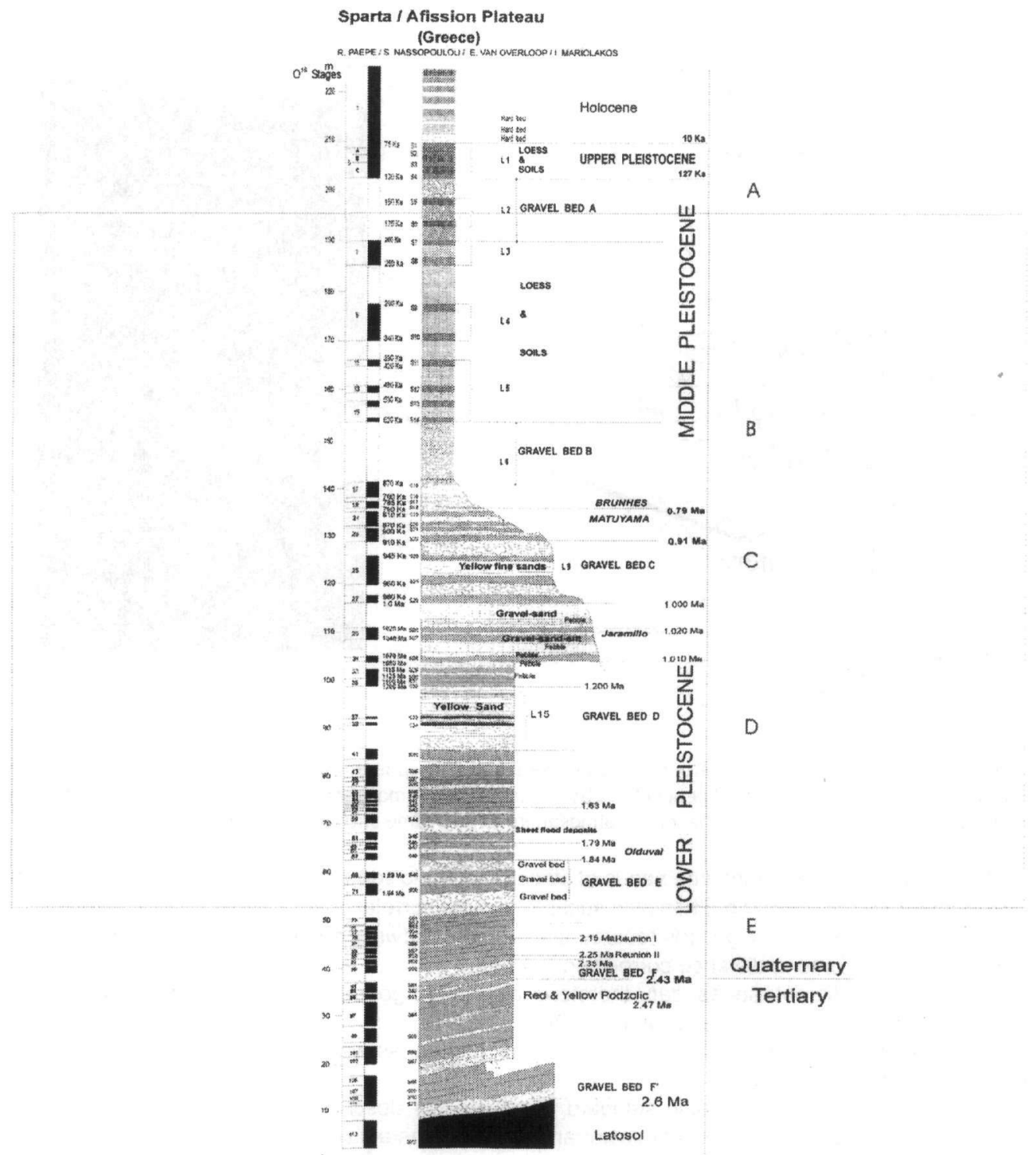

Figure 2a. Quaternary section of Sparta/Afission

The lithostratigraphic sequence of as shown in Figure $2 a$ is described in Table 1 hereunder. It is correlated (Figure $2 \mathrm{~b}$ ) tc a similar soil-stratigraphic loess sequence from Huanglin (Loess Plateau of Central China described by Han Jiamao et al. 1991) on the right of the same figure.

Detailed presentations of the section were already published earlier (e.g. Paepe et al. 1990, 1996). Differences with previous published data relate mainly to observations made in more recent sections such as those recorded at the new Athens 'Elefteriou Venizelos' airport while under construction in the nineties's (currently under study for publication). 


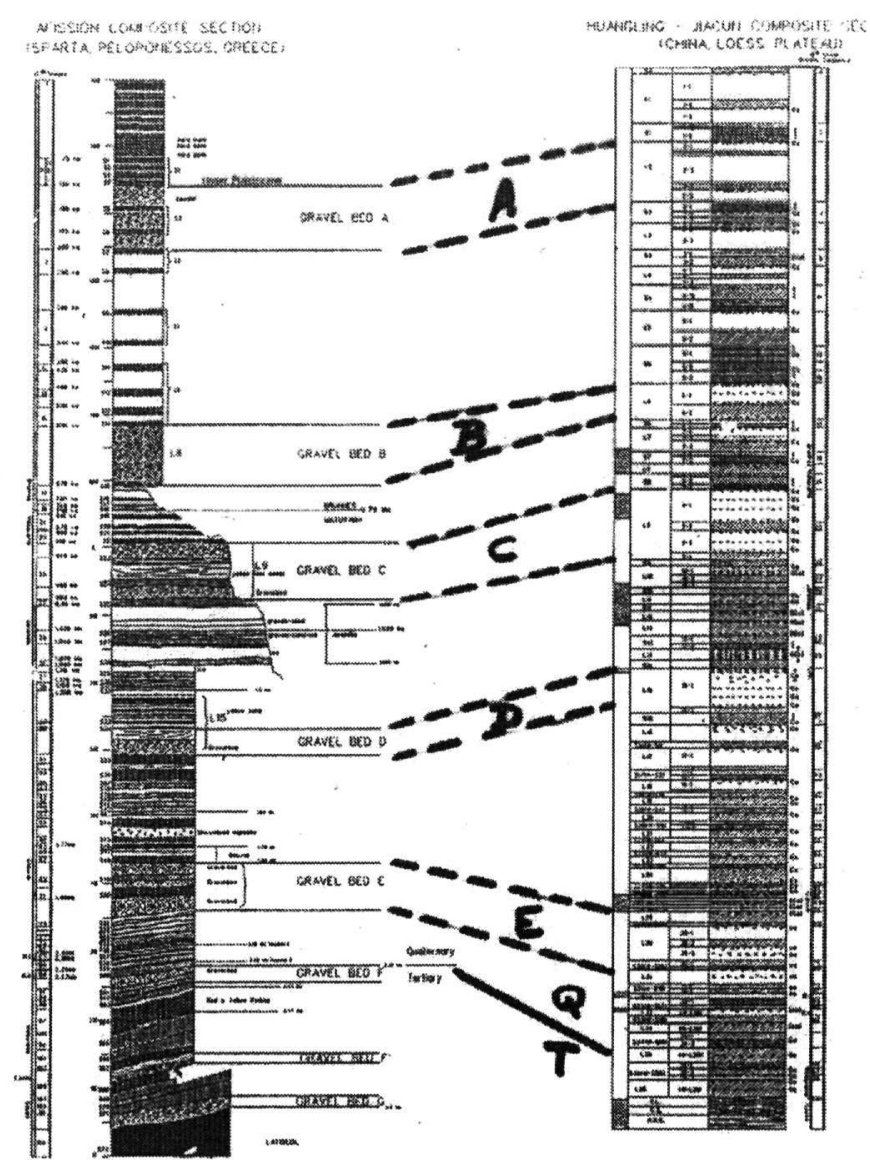

Figure 2b. Comparison Affision and Huangling Loess

It resulted in first: the definite threefold subdivision of the land-soil Pliocene and second: the attribution of an Upper Miocene age to the latosol at the base of this sequence which previously was considered as Middle Pliocene. At the airport section another gravel bed and red soil appeared clearly above Gravel Bed $\mathrm{F}^{\prime}$ which was faintly developed at the Afission section as presented on the left in Figure 2. Henceforth, the latter became labelled Gravel Bed $G$ while the gravel bed above the first red soil, not labelled so far in the Afission section, became Gravel Bed F' as described in Table 1. Depth, Description, Interpretation, Age and IOS (ocean 'isotopic oxygen stage') are reported at each successive level.

Table 1. Description of the lithostratigraphic record

\begin{tabular}{|c|c|c|}
\hline Depth & Description & Interpretation/Age/IOS \\
\hline $000-006 m$ & $\begin{array}{l}\text { LATOSOL correlated with Upper Miocene peatbogs } \\
\text { at Choremi DEl excavation pit }\end{array}$ & Upper Miocene/10 Ma \\
\hline $006-027 m$ & $\begin{array}{l}7 \text { thick series of GRAVEL BEDS (GB G, GB F' and } \\
\text { GB F) each overlain by sands and loams and by a } \\
\text { deep red s'il } \\
\text { Australopithecus afarensis extincts about } 2.6 \mathrm{Ma}\end{array}$ & $\begin{array}{l}\text { Lower, Middle and Upper Pliocene } \\
\text { respectively } 7.5 \mathrm{Ma}, 5 \mathrm{Ma} \text { and } 2.6 \mathrm{Ma} \text {; } \\
\text { soils correlated with IOS } 103 \text { through } 91 \\
\text { (in GBF' Gauss/Matuyama } 2.6 \mathrm{Ma} \text { ) }\end{array}$ \\
\hline $027-043 m$ & $\begin{array}{l}11 \text { thin series of sand, loams, gravels and red soils } \\
\text { topped by thick GRAVEL BED E } \\
\text { It is the habitat of Australopithecus africanus }\end{array}$ & $\begin{array}{l}\text { Lowermost Pleistocene }(2.4-1.9 \mathrm{Ma}) \text { as } \\
\text { GBF' ( } 2.6 \mathrm{Ma}) \text { occurs below these series } \\
\text { Ending up at the Olduvai Event. } \\
\text { soils correlated with IOS } 89 \text { through } 69\end{array}$ \\
\hline
\end{tabular}




\begin{tabular}{|c|c|c|}
\hline $043-064 m$ & $\begin{array}{l}14 \text { thin series of sand, loams, gravels and red soils } \\
\text { topped by thick GRAVEL BED D } \\
\text { Habitat of Homo habilis \& Zinjanthropus }\end{array}$ & $\begin{array}{l}\text { Middle Lower Pleistocene }(1.9-1.4 \mathrm{Ma}) \\
\text { soils correlated with IOS } 67 \text { through } 41 .\end{array}$ \\
\hline $064-091 m$ & $\begin{array}{l}8 \text { thin series of sand, loams, gravels and red soils } \\
\text { topped by thick GRAVEL BED C } \\
\text { Thick eolian sands at start: } 1.4 \text { Ma Great Drought } \\
\text { Habitat of homo erectus \& Sinanthropus }\end{array}$ & $\begin{array}{l}\text { Upper Lower Pleistocene }(1.4-0,9 \mathrm{Ma}) \\
\text { soils correlated with IOS } 39 \text { through } 25 \\
\text { Cobb ( } 1.99 \mathrm{Ma}) \text { and Jaramillo }(1.07 \mathrm{Ma}) \\
\text { positive Events occur in these series }\end{array}$ \\
\hline $0.91-108 m$ & $\begin{array}{l}4 \text { thin series of sands, loams, less gravels and } \\
\text { weak red soils topped by thick GRAVEL BED B } \\
\text { indicating transitional climate from wet to drought } \\
\text { Extinction of Homo erectus \& Sinanthropus }\end{array}$ & $\begin{array}{l}\text { Lower Middle Pleistocene }(0.9-0.6 \mathrm{Ma}) \\
\text { soils correlated with IOS } 23 \text { through } 17 \\
\text { Brunhes/Matuyama boundary at } 0.79 \mathrm{Ma}\end{array}$ \\
\hline $108-145 m$ & $\begin{array}{l}10 \text { thick series of sands, loams, less gravels but } \\
\text { strong red soils topped by thick GRAVEL BED A } \\
\text { Soils more widely spaced through time indicating } \\
\text { climate changing into general drought } \\
\text { Dawn of Hcmo sapiens neanderthalensis }\end{array}$ & $\begin{array}{l}\text { Middle Middle Pleistocene }(0.6-0.1 \mathrm{Ma}) \\
\text { soils correlated with IOS } 15 \text { through } 7\end{array}$ \\
\hline $145-148 m$ & $\begin{array}{l}5 \text { moderately developed soils with thin gravelly } \\
\text { layers in between } \\
\text { Detailed study is provided at Koroni section }\end{array}$ & $\begin{array}{l}\text { Upper Pleistocene }(0.127 \mathrm{Ka}-10 \mathrm{Ka}) \\
\text { soils correlated with IOS } 5 \text { through } 3 \text { as } \\
\text { the three lowermost ones are grouped as } \\
\text { Last Interglacial and two uppermost ones } \\
\text { as Last Glacial Interstadials: }\end{array}$ \\
\hline $148-160 m$ & $\begin{array}{l}8 \text { moderately developed soil in alluvial sediments } \\
\text { Detailed study is provided at Marathon section }\end{array}$ & $\begin{array}{l}\text { Holocene (Last } 10 \mathrm{Ka} \text { or } 10.000 \text { years) } \\
\text { The whole Holocene soil compound corre } \\
\text { lates with IOS } 1 .\end{array}$ \\
\hline
\end{tabular}

Main characteristics of the Sparta/Afission record:

$>$ Above the basal Miocene latosol overlain by Gravel Bed G, follows a threefold series of equally red latosolic-like geosoils of the Pliocene. GBF' (containing the $2.6 \mathrm{Ma}$ Gauss-Matuyama keybed) occurs in the middle of them so that Gravel Bed F on top of these Pliocene geosoils and covered by the complete sequence of the Pleistocene (and the Holocene at the very top of it) is the Plio-Pleistocene boundary.

$>$ This Plio-Pleistocene boundary is secured by two datings: first the GBF' gravel deposit containing the Gauss/Matuyama boundary of $2.6 \mathrm{Ma}$ (as is also the case in the loess of China); second the Reunion $1 \& 2$ reversals at respectively 2.15 and $2.25 \mathrm{Ma}$ occurring right a'jove the uppermost GBF gravel deposit. Henceforth, the beginning of the Pleistocene is estimated at $2.4 \mathrm{Ma}$. This complies with the earlier assumption of the start of the Pleistocene on land is at $2.43 \mathrm{Ma}$ (Zagwijn \& Paepe 1968).

$>$ The Pleistocene sequence which follows above, is composed of a sixfold cyclothem system of 6 stratigraphically spaced Gravel Beds (GB) at $400 \mathrm{Ka}$ time intervals. This cycle was computed Van Overloop \& Paepe (1998) on basis of the Sparta/Afission geosoil record. It encompasses the $400 \mathrm{Ka}$ cycle of the deepsea record. Actually, the total timespan of 6 cyclothems is $6 \times 400 \mathrm{Ka}=2.4 \mathrm{Ma}$. This landbound figure differs considerably from the marine-bound Calabrian boundary locating the Plio-Pleistocene boundary a. $1.78 \mathrm{Ma}$.

$>$ Paepe et al. (1995) made an attempt to subdivide the $2.4 \mathrm{Ma}$ Pleistocene record climatically on basis of the $400 \mathrm{Ka}$ periodicity, into Climatic Superstages called respectively 'Thermomers' with warmer interglacials and 'Cryomers' with colder interglacials. The six cyclothems were subsequently labelled as T1 (between GB F and GB E), C1 (between GB E and GB D), T2 (between GB D and GB C), C2 (between GB C and GB B), T3 (between GB B and GB A) and finally C3 (between GB A and later). It explains the cyclic variation in intensity of the interglacials viz. interstadials every $400 \mathrm{Ka}$. The Pleistocene in Greece starts with T1, a warm cyclothem with four warm interglacials.

$>$ Correlation at the level of the six cyclothems and related geosoil series, between far distanciated sections such as of Lochuan on the Central Loess Plateau in China (Liu 1985 ), or as the Greek type of sedimentary sequences in the West- (Congo, Burundi, Uganda) and East-African Rifts (Tanzania) (Van Overloop \& Paepe 1998), prove to be 
quite feasib!e and add to confirm the time-stable character of these cycles at any place of the globe.

> This 'time-stable' character infers moreover an extraterrestrial most probably planetary origin. Paepe et al. (1995) previously computed this geosoil time-stability to be of the order of $0.1 \%$ at the 1.000 .000 time interval. This implies a possible soil-stratigraphic shift of maximum 1yr/1000yrs or 100yrs for one Milankovitch eccentricity cycle of at random $100.000 \mathrm{yrs}$. Considering that this Milankovitch eccentricity cycle corresponds to an Interglacial-Glacial cycle (similar to the Last Interglacial - Last Glacial Cycle) is inferring that all Interglacial-Glacial cycles of the long-term Pleistocene record obey to the same law of time-stability.

$>$ The question remains though why every fourth eccentricity cycle of the $400 \mathrm{Ka}$ cycle terminates in the deposition of a hughe gravel bed $(A, B ; C, D, E, F)$ whatever one is dealing with a thermomer or with cryomer. Such hughe gravel beds can only originate when steady rock fragmentation under desertic environmental circumstances can sufficiently supply such hughe amounts of basic coarse clastic material. Therefore, it is hereby assumed that the Gravel Beds infer phases of drought and cooling off which in the fourth eccentricity cycle could have been triggered by other planetary forcings such as the obliquity $(41 \mathrm{Ka})$ and the precession $(23 \mathrm{Ka})$ just to mention the Milankovitch cycles only. Van Overloop \& Paepet (1998) is, however, suggesting that other cyclicities may intervene as well in addition to the classical Milankovitch cycles.

\subsubsection{Section Kandanos}

The Kandanos section lies along the road to Kandanos at about $3 \mathrm{~km}$ distance when arriving from Maleme. The geological sequence is exactly the same as the one of Sparta/Afission in the Peloponnesus. The sequence starts here also with the Miocene latosol followed upwards by a series of alternating red soils and gravels as was already earlier described (Paepe et al. 1996).

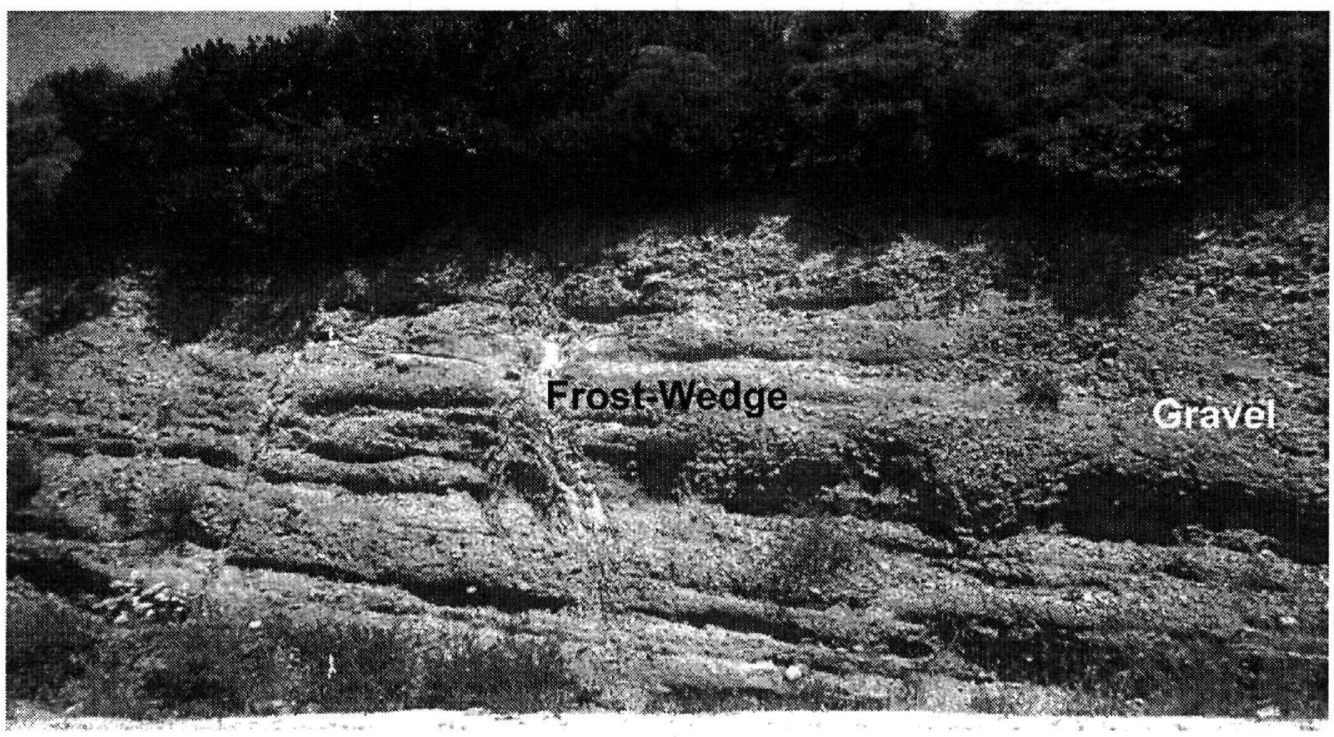

Figure 3. Quaternary section of Kandanos (Crete) showing an alternating series of lower Pleistocene red soils and gravels with a frost-wedge zone in the middle and to the left of it, a young fault line.

However, at many stages of the Kandanos record cold features, like frostwedges indicating periodic permafrost occurrences, appeared to exist between the red geosoil sequences. as is illustrated in Figure 3 and on the left diagramme in Figure 4. Recently similar frost features were observed in the Garazo-Anogia area. The frostwedge sequence indicates that several ice-ages 
occurred throughout the Pleistocene in Crete, i.e. the most southern part of Europe (Paepe \& Van Overloop 2001).

\section{LONG, MIDDLE AND SHORT TERM RECORD OF THE PLEISTOCENE}

\subsection{Pleistocene Long Term Record (Recent till 2.4 Ma)}

The position of the Crete frostwedge sequence as indicated in Figure 4 by the inverted black triangular arrows, show that cold climatic conditions prevailed at regular times throughout the Pleistocene on the island of Crete. When considering similar occasional observations in the Peloponnesus and elsewhere in mainland Greece in general, the regular Crete frostwedge sequence may then be considered as representative for the whole region.
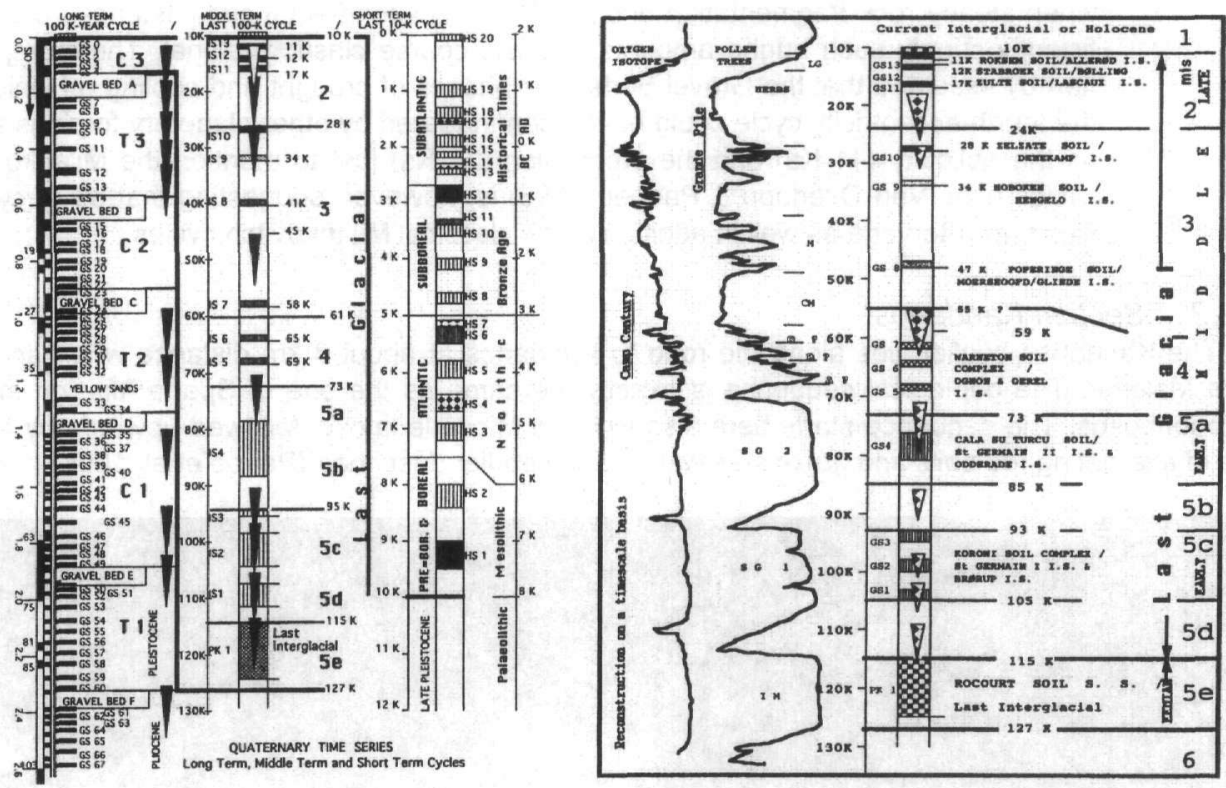

Figure 4. To the left, table of the Pleistocene Long Term, Middle Term and Short Term Record. To the right, detail of the Pleistocene Midlle Term Record.

The Greek Pleistocene record is thus characterised by at least 11 regularly occurring strong cold (frostwedge) stages over the last $2.4 \mathrm{Ma}$ with intervals of $200 \mathrm{Ka}, 400 \mathrm{Ka}$ and $600 \mathrm{Ka}$ : within the Lower Pleistocene occurring at $2.3 \mathrm{Ma}, 1.9 \mathrm{Ma}, 1.7 \mathrm{Ma}, 1.4 \mathrm{Ma}, 1.2 \mathrm{Ma}, 1.0 \mathrm{Ma}$; within the Middle Pleistocene occurring at $0.5 \mathrm{Ma}, 0.4 \mathrm{Ma}, 0.3 \mathrm{Ma}$ and $0.2 \mathrm{Ma}$ inferring cold stage recurrences at 100 $\mathrm{Ka}$. One specific $100 \mathrm{Ka}$ cycle occurs above Gravel Bed A encompassing the entire range of the last Cryomer-C3. It corresponds to the Pleistocene Middle Term Record studied hereunder.

\subsection{Pleistocene Middle Term Record (127 Ka - $10 \mathrm{Ka})$}

The Pleistocene Middle Term Record was recorded at Koroni in the Peloponnesus, and corresponds by definition to the time span of the Last Interglacial - Last Glacial sequence before the Holocene: $127 \mathrm{Ka}-10 \mathrm{Ka}$. It correlates with the last eccentricity cycle of Milankovitch of at random $100 \mathrm{Ka}$. Between the Last Interglacial Geosoil (127 Ka - $115 \mathrm{Ka}$ ) and the Holocene Geosoil (10 Ka) 13 interstadial Geosoils occur interfering with 6 levels of frostwedges. It subdivides the whole sequence into an initial warmer period lasting from $115 \mathrm{Ka}$ till $73 \mathrm{Ka}$ and a firm cold period from $73 \mathrm{Ka}$ till $17 \mathrm{Ka}$. After the lattei date, the temperature curve is steeply rise to the Holocene at $10 \mathrm{Ka}$. The 
trend revealed in the soil and frostwedge sequence is reflected in the pollen record of La Grande Pile in NE France, and in the ice oxygen isotopic record of Camp Century in Greenland.

\subsection{Holocene Short Term Record (10 Ka)}

As indicated in the third column on the left table in Figure 4, twenty alternating dryer-cooler and wetter-warmer cycles occurred within the last $10 \mathrm{Ka}$ (Holocene or current interglacial) as revealed in the coastal plain of Marathon. These geological stages are encompassing the prehistoricalarchaeological periods of the last $10 \mathrm{Ka}$.

\section{CONCLUSION}

Peloponnesus and Crete are probably offering the best possible standard sections for Eastern Mediterranean Pleistocene Series. The geological sections of Sparta/Affision (Peloponnesus) and Kandanos (Crete) reve aled a complete Pleistocene land record based on soil-stratigraphic sequences. The latter provided a Long Term and a Middle Term Pleistocene record with in addition the Holocene Short Term record on top of the stratigraphic ladder. The latter could easily be correlated with the archaeological chronostratigraphy of Greece.

\section{REFERENCES}

Han Jiamao, J.J. Hus, R. Paepe, R.E. Vandenberghe and Liu Tungsheng, 1991. The Rock Magnetic Properties of the Malan and Lishi Formations in the Loess Plateau of China, 30-47. In : Liu Tungsheng (eds), Environment anc' Global Change, Science Press, Beijing, China.

Liu, T., 1985. Central Loess Plateau in China. Proceedings Academia Sinica. Special Issue, 226pp.

Zagwijn, W.H. and Paepe, R., 1968. Die Stratigraphie der Weichselzeitlichen Ablagerungen der Niederlande und Belgiens. Eiszeitalter und Gegenwart, 19, 126-146.

Paepe, R., Mariolakos, I., Van Overloop, E., and Keppens, E., 1990. Last Interglacial-Glacial Geosoil Traverse (from stratotypes in the North Sea Basin and in the Eastern Mediterranean), Quaternary International, 5, 5770.

Paepe, R., Hadziotou, M., and Van Overloop, E., 1995. Twenty Cyclic Pulses of Drought and Humidity during the Holocene. In : Finkl, C.W. Jnr. (ed.), Holocene Cycles. Journal of Coastal Research, Special Issue 17, 55-61.

Paepe, R., Mariolakos, I., Vassopoulou, S., Van Overloop, E., and Vouloumanos, N., 1996. Quaternary Periodicities of Drought in Greece. In: Angelakis, A.N. and Issar, A.S. (eds), Diachronic Climate Impacts on Water Resources, NATO ASI Series I: Global Environmental Change, Vol. 36, 77 - 110.

Paepe, R., and Van Overloop, E., 2001. Permafrost Equivalents from Boreal to Tropical Zones. In: R. Paepe and V. Melnikov (eds), Permafrost response on economic development, environmental security and natural resources, NATO ASI Series 2, Environmental Security, Vol. 76, 151-184.

Shackleton, N.J., Berger, A. and Peltier, W., 1990. An alternative astronomical calibration of the Lower Pleistocene time-scale based on ODP Site 677. In: Transactions Roy. Soc. Edinburgh, Earth Sciences, 81, 251261.

Van Overloop, E., and Paepe, R., 1998. The Quaternary Geology around the Great Lakes in Central Africa. Proceedings Int. Conf. on Tropical Climatology, Meteorology and Hydrology, 142-175. 